\title{
Moth-Eaten Essential Syphilitic Alopecia in Human Immunodeficiency Virus-Positive Patient: A Case Report
}

Satiti Retno Pudjiati*, Beatrix Novandri Uly, Carolina Kurniawati, Devi Artami Susetiati, Agnes Sri Siswati

Dermatology and Venereology Department, Faculty of Medicine, Nursing and Public Health Universitas Gadjah Mada / RSUP Dr. Sardjito

Yogyakarta, Indonesia

*Corresponding Author: Satiti Retno Pudjiati, Dermatology and Venereology Department, Faculty of Medicine, Nursing and Public Health Universitas Gadjah Mada / RSUP Dr. Sardjito Yogyakarta, Indonesia.

Received date: January 29, 2021; Accepted date: April 02, 2021; Published date: April 05, 2021

Citation: Satiti R Pudjiati, Beatrix N Uly, C Kurniawati, Devi A Susetiati, Agnes S Siswati. (2021) Moth-Eaten Essential Syphilitic Alopecia in Human Immunodeficiency Virus-Positive Patient: A Case Report. International Journal of Clinical Case Reports and Reviews. 6(5); DOI:10.31579/2690-4861/111

Copyright: (C) 2021 Satiti Retno Pudjiati, This is an open-access article distributed under the terms of the Creative Commons Attribution License, which permits unrestricted use, distribution, and reproduction in any medium, provided the original author and source are credited.

Abstract
Hair loss is rare to be reported as sole manifestation of secondary syphilis. Syphilitic alopecia consists of
symptomatic syphilitic alopecia that presents with other secondary syphilis manifestation, and essential syphilitic
alopecia which can be patchy ("moth-eaten" type), diffuse, or combination without other manifestations of
secondary syphilis. Here we report a case of secondary syphilis in patient with Human Immunodeficiency Virus
(HIV) that present with moth-eaten alopecia as a sole manifestation. A 35-year-old male with HIV complained
hair loss on his scalp and eyebrows. Physical examination showed non scarring moth-eaten alopecia on his scalp
and lossof lateral third of his eyebrows without other lesions. Serological test for syphilis was positive. He was
treated with 2.4 millions unit of benzathine penicillin G (BPG), single dose intramuscular injection. Six months
after injection, patient showed clinical and serological improvement. Syphilitic alopecia cannot be ruled out in
patients with non scarring hair loss with unclear etiology. Serological tests are recommended especially for patients
with history of high risk sexual behaviour.
Keywords: moth-eaten alopecia; secondary syphilis; HIV

\section{Introduction}

Syphilitic alopecia (SA) is a rare cutaneous manifestation of secondary syphilis, ranging from 2.9 to $7 \%$ of all cases. Its presentation varies from diffuse to moth-eaten pattern, or combination of both. The scalp is the most commonly affected area. However, eyebrows, eyelashes, hair in axilla, pubic area, chest, and legs can also be affected. Of these, motheaten SA is the most commonly found and it presents as patchy alopecia in varying size, indistinct borders resembling the hair was eaten by moth. It mainly occurs in the parieto-occipital area [3, 4]. In 1940, Mc Carthy divided SA into 2 types including symptomatic syphilitic alopecia and essential SA with alopecia as the only presenting symptom [1, 2] Motheaten alopecia accounted for 2.9 to $48 \%$ of all reported cases of secondary syphilis and very rarely reported as a sole manifestation of secondary syphilis. Delay in diagnosis can increase the risk of syphilis progression to tertiary stage and resulting mortality $[5,6]$.

\section{Case Presentation}

A 35-year-old male, came to the dermatology and venereology outpatient department in Dr. Sardjito Hospital with chief complaint of hairloss on the scalp and eyebrows. Three months prior to consultation, he complained of some small areas of hair loss on his scalp, which then increased in number and size. He also noted to have thinning of his lateral eyebrow. There were no itch and pain sensation. Patient did not seek consult and no medication was applied nor taken. Patient admitted history of painless ulcer on his genital area prior to the hairloss but he did not seek consultation for the ulcer and it was spontaneously healed. Patient denied history of trauma prior to the ulcer and hairloss. Patient is bisexual and has 1 female partner and multiple male partners. Patient is known to have HIV and has started treatment using nevirapine, lamivudine and zidovudine. Upon examination, the Cluster of Diffrentiation (CD) 4+ was 301 cells / mm3. Venereal Disease Research Laboratory (VDRL) titer was 1:32 and Treponema Pallidum Hemagglutation Assay (TPHA) was positive.

On that point, patient appeared well, vital signs were within normal limits and no palpable lymph nodes. There were multiple patches of hairloss measuring 0.5 to $1 \mathrm{~cm}$ in size over the temporal, parietal and occipital regions (Figure 1A). No sign of inflammation was noted. The hair pull test was negative. Alopecia patches were also noted on the lateral third of both eyebrows (Figure 2A). No active lesions over other body parts. The patient was diagnosed as a case of moth-eaten essential syphilitic alopecia. He was given a single dose of BPG 2.4 million units intramuscularly. Two months after treatment, the hair was almost fully regrowth (Figure 1B\&2B) and on the six months follow up, VDRL titer has decreased to $1: 2$. 


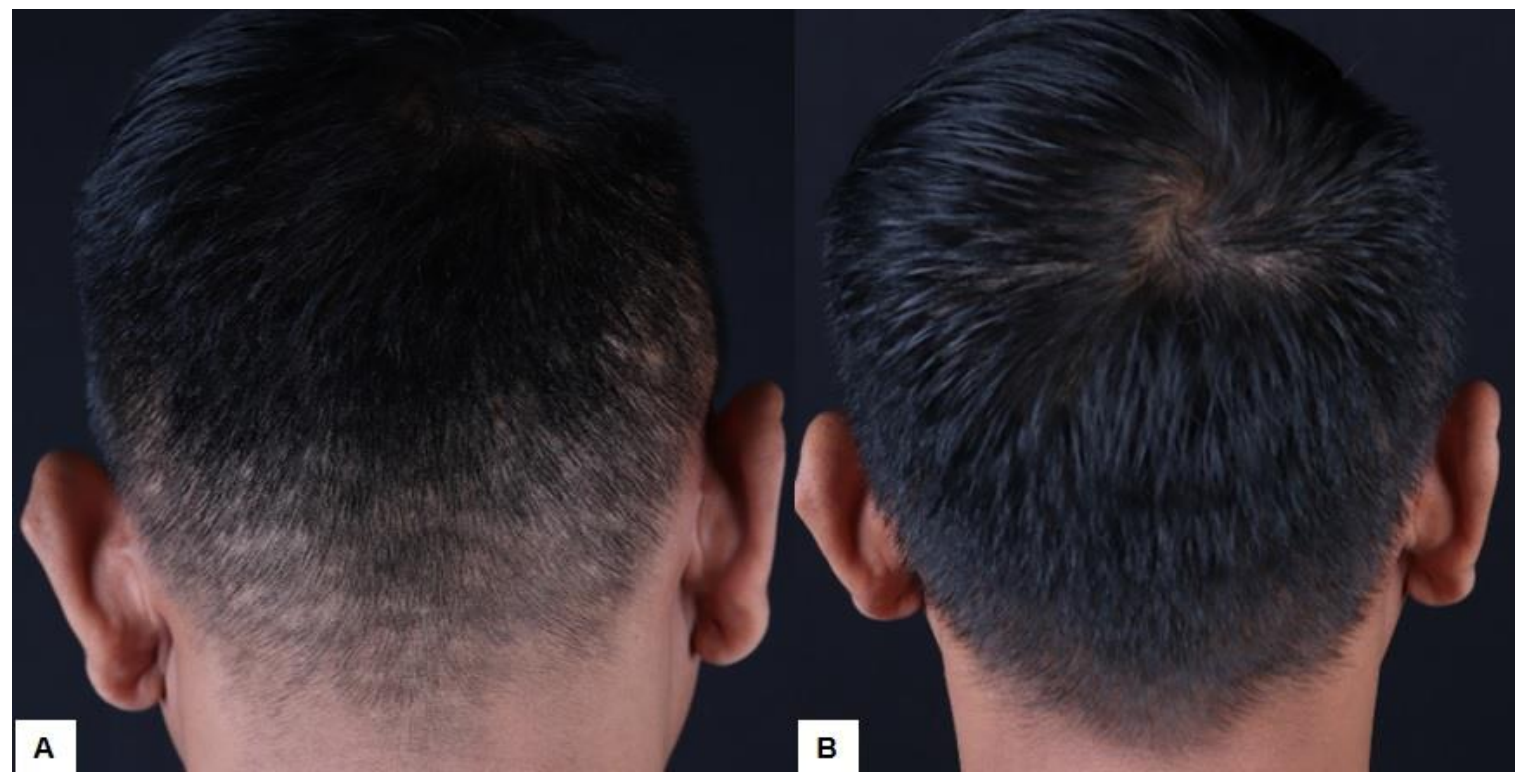

Figure 1: A, Multiple moth-eaten alopecia patches before BPG injection. B, Two months after BPG Injection.

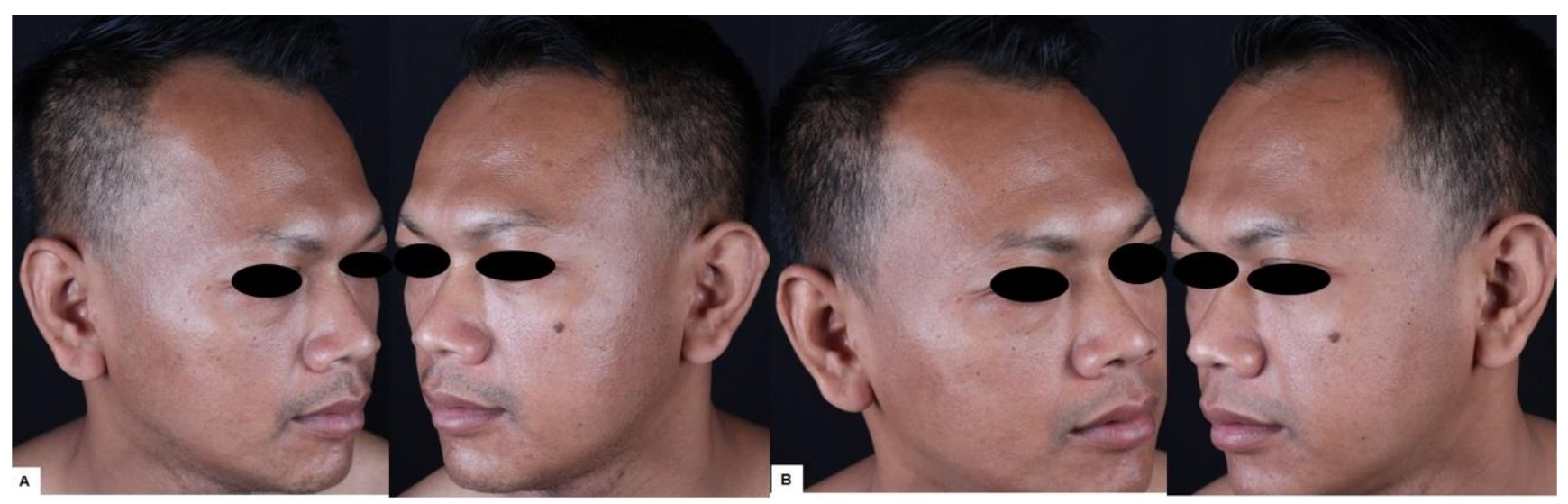

Figure 2: A, Diffuse alopecia on lateral third eyebrows. B, Two months after BPG Injection.

\section{Discussion}

Syphilis is a systemic disease caused by the spirochaete Treponema pallidum. The first stage is known as primary syphilis, characterized by the presence of chancre. Chancre is a round or slightly elongated clean painless ulcer, $0,5-2 \mathrm{~cm}$ in diameter, firm or rubbery with raised edge, and associated with regional lymphadenopathy. It usually heals over a 4-6 weeks period. Secondary syphilis develops 4 to 10 weeks after chancre. Skin manifestations including condyloma lata, alopecia, palmar or trunk rash, and papulosquamous rash. Secondary syphilis can resolve spontaneously in 4-12 weeks or can progress into tertiary syphilis [7].

Syphilitic alopecia is a rare manifestation of secondary syphilis and occurs in approximately $4 \%$ of cases. In 1940, Mc Carthy divided SA into 2 types including symptomatic SA and essential SA with alopecia as the only presenting symptom. Essential alopecia has three distinct clinical patterns, consist of moth-eaten alopecia or patchy, diffuse and mixed alopecia $[2,3,4]$. The moth-eaten alopecia pattern is the most commonly found and pathognomonic for secondary syphilis. The patches vary in size and occur mainly in the parieto-occipital area. It can affect scalp hair and also other hairy body parts such as lateral third of the eyebrows [3, 4].

The exact pathogenesis of SA is still unknown. In 1991, Lee and Hsu speculated that peribulbal inflammation in 9 scalp biopsies indicated that
SA was caused by locally invading spirocetes, even though the spirochaete was not detected. Apart from follicular changes, other histopathologic findings were similar to those found in siphilide macules in other areas of the body. These findings suggest that the same pathological process in mucocutaneous syphilis can also contributed to SA [8]. In 2006, Nam-Cha et al. detected T. pallidum in an immunohistochemical study from SA patient who was also HIV positive. Spirochaetes are detected in the peribulbar area and penetrate into the follicular matrix. This is the first study showed an organism has been detected in hair follicles and supports the speculation that T. pallidum may be responsible for SA [9].

Blood work up of syphilis serological test like VDRL and TPHA play important role in confirming the diagnosis. The VDRL test usually begins to be detected around 4 to 5 weeks after infection, and achieved $100 \%$ sensitivity by week 12 . This test is found to be unreactive in $25 \%$ to $30 \%$ of cases during late latent syphilis [10].

There were several case reports for the treatment of SA. Doche et al reported 1 case of diffuse essensial SA in an HIV-negative Caucasian male, the patient was successfully treated using erythromycin $500 \mathrm{mg}$ twice daily for 30 days [1]. Hernández-Bel also reported an HIV-negative patient with moth-eaten alopecia which was successfully treated using 3 doses of BPG injection. The syphilitic alopecia resolves with antibiotic 
therapy within $8-12$ weeks $[2,11,12]$. Beside hair regrowth, success of the treatment is defined by fourfold decrease of VDRL titer within 12 to 24 months although it could be slower in people with HIV [11, 12]. The patient in our case was given only single dose of BPG 2.4 million units intramuscular injection which provided significant clinical improvement both for scalp hair and also eyebrows after 2 months and decrement of VDRL titer to $1: 2$ after 6 months.

\section{References}

1. Doche I, Hordinsky M.K, Valente Y.S, Romiti R, Tosti A. (2017) Syphilitic Alopecia: Case Reports and Trichoscopic Findings. Skin Appendage Disord. 3:222-224.

2. Hernández-Bel. P, Unamuno B, Sánchez-Carazo J.L., Febrer Y, Alegre V. (2013) Syphilitic Alopecia: A Report of 5 Cases and a Review of the Literature. Actas Dermosifiliogr.104:512-517.

3. Vafaie J, Weinberg JM, Smith B, et al. (2005) Alopecia in Association With Sexually Transmitted Disease: A Review. CME. 76:361-366.

4. Costa MC, Peres AS, Queiróz AJR, Medeiros NS, Costa IMC. (2018) Nonspesific Diffuse Alopecia as a Single Manifestation of Syphilis Infection: Clinical and Trichoscopic Features. Int J Dermatol. 57(5):593-595.
5. Bi MY, Cohen PR, Robinson FW, Gray JM. (2009) Alopecia syphilitica-report of a patient with secondary syphilis presenting as moth-eaten alopecia and a review of its common mimickers. Dermatol Online J. 15(10):6.

6. Milan B, Milica M, Dubravka S, et al. (2012) Syphilitic Alopecia in HIV Infected Homosexual Men: Case Reports. Acta Dermatovenereol Croat. 20:48-56.

7. Nyatsanza F, Tipple C. (2016) Syphilis: presentations in general medicine. Clin Med. 16:184-188.

8. Lee JY, Hsu ML. (1991) Alopecia syphilitica, a simulator of alopecia areata: histopathology and differential diagnosis. J Cutan Pathol. 10: 87.

9. Nam-Cha, S.H., et al. (2007) Alopecia syphilitica with detection of Treponema pallidum in the hair follicle. J Cutan Pathol. 34 (S1):37-40.

10. Nayak S, Acharjya B. (2012) VDRL Test and Itss Interpretation. Indian J Dermatol. 57(1):3-8.

11. Dai S, Wang H, Lin Z. (2019) Moth-eaten alopecia in secondary syphilis. Int J Infect Dis. 82:6-11.

12. Piraccini BM, Broccoli A, Starace M, Gaspari V, D' Antuono A, Dika E, et al. (2015) Hair and Scalp Manifestations in Secondary Syphilis: Epidemiology, Clinical Features and Trichoscopy. Dermatology. 231:171-176.

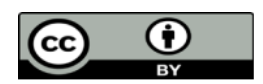

This work is licensed under Creative Commons Attribution 4.0 License

\section{To Submit Your Article Click Here: Submit Manuscript}

DOI: $10.31579 / 2690-4861 / 111$
Ready to submit your research? Choose Auctores and benefit from:

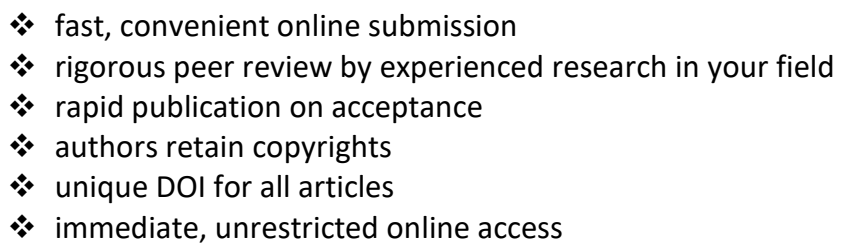

At Auctores, research is always in progress.

Learn more www.auctoresonline.org/journals/international-journal-ofclinical-case-reports-and-reviews 